Ю Б И Л Е И

УДК 811.511. 131(092)

\author{
Л. Л. Карпова
}

ТАЙНЫ ТОПОНИМИЧЕСКОГО ЗВУЧАНИЯ

(К ЮБИЛЕЮ Л. Е. КИРИЛЛОВОЙ)

\begin{abstract}
Статья посвящена юбилею удмуртского лингвиста, заслуженного деятеля науки, кандидата филологических наук Людмилы Евгеньевны Кирилловой. Рассматривается ее научная и творческая деятельность, освещается вклад ученого в развитие удмуртского языкознания, прежде всего в изучение удмуртской ономастики. Ее научные труды востребованы не только среди академического сообщества и преподавателей высшей школы, но и всеми, кто интересуется традиционной культурой. Ею проведено большое количество топонимических и фольклорно-диалектологических экспедиций, ареал которых, помимо Удмуртской Республики, охватывает Республику Татарстан и Кировскую область. Имя удмуртского лингвиста известно не только в российском масштабе, но и за его пределами. Л. Е. Кириллова - неоднократный участник международных конференций и конгрессов.
\end{abstract}

Ключевые слова: финно-угроведение, удмуртский язык, ономастика, топонимика, юбилей, Л. Е. Кириллова.

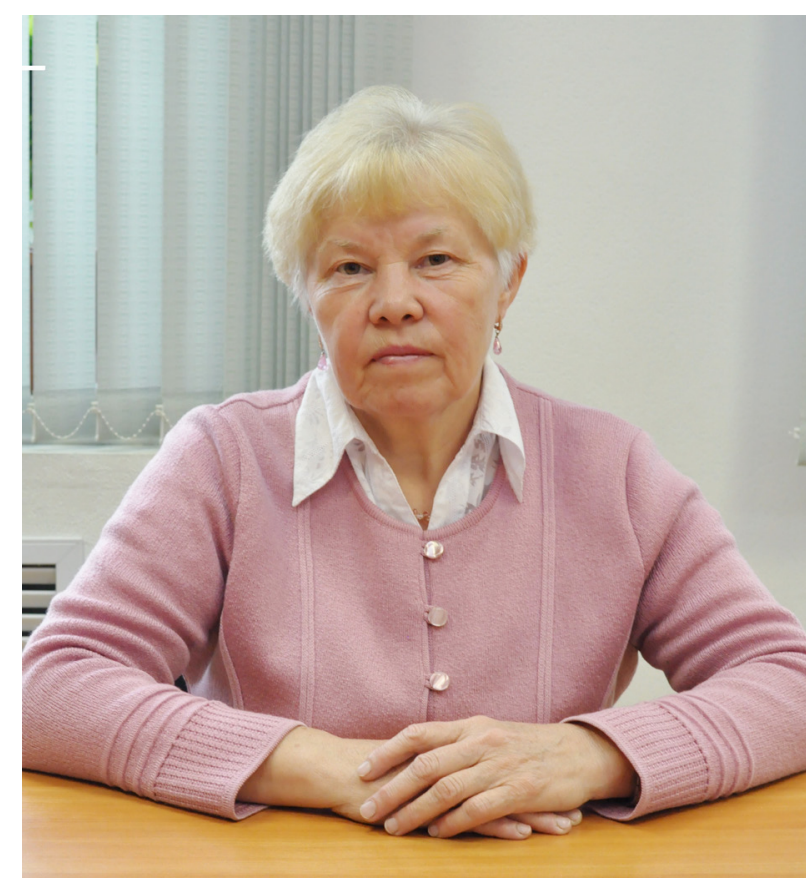

Людмила Евгеньевна Кириллова - одна из видных и талантливых деятелей науки, известный финно-угровед, ведущий специалист в области удмуртской ономастики и топонимики, кандидат филологических наук, старший научный сотрудник отдела филологических исследований Удмуртского института истории, языка и литературы Удмуртского федерального исследовательского центра УрО РАН. Научная деятельность ученого получила высокую оценку как среди отечественных финно-угроведов, так и за рубежом. Её добросовестный труд отмечен многими наградами: Почетной грамотой Профсоюза работников РАН (1999), Почетной грамотой Госсовета Удмуртской Республики (2001), Почетной грамотой Удмуртской Республики (2014), Почетной грамотой МарНИИ языка, литературы и истории им. В. М. Васильева (2006), Почетной грамотой Удмуртской 
республиканской организации профсоюза работников народного образования и науки РФ (2006), Почетной грамотой Министерства национальной политики УР (2011) и др. За значительный вклад в удмуртскую филологическую науку ей присвоено почетное звание «Заслуженный деятель науки Удмуртской Республики» (2005).

Родилась Л. Е. Кириллова (Зверева) в д. Якшур Завьяловского района Удмуртской АССР. Окончив Якшурскую среднюю школу, в 1972 г. поступила в Удмуртский государственный университет на удмуртское отделение филологического факультета, который она успешно завершила в 1977 г. В университете она слушала лекции по родному языку у таких авторитетных ученых, как И. В. Тараканов, В. К. Кельмаков, сыгравших, безусловно, немаловажную роль в определении ее научных интересов. В студенческие годы она еще крепче полюбила родной язык, показала себя способным исследователем. В вузе активно включилась в жизнь факультета: была членом академкомиссии и членом профкома, старостой лингвистического кружка (рук. В. К. Кельмаков). В 1979 г., будучи студенткой II курса, участвовала в работе студенческой научной конференции в Тартуском государственном университете (Эстония). После окончания университета перед Л. Е. Кирилловой открылись две реальные возможности: 1) посвятить себя профессиональной деятельности учителя или 2) стать одним из исследователей финно-угорских языков. Она выбирает вторую и в 1977 г. по распределению приходит в сектор языка Удмуртского научно-исследовательского института. После года работы в должности младшего научного сотрудника ее направили на стажировку в Институт языкознания АН СССР, в сектор финно-угорских языков. Работала по теме «Микротопонимия бассейна реки Иж Удмуртской АССР» под научным руководством известного удмуртского исследователя, кандидата филологических наук Т. И. Тепляшиной.

В этом же институте в 1980-1983 гг. обучалась в аспирантуре под руководством видного и авторитетного ученого с мировым именем, доктора филологических наук, членакорреспондента АН СССР Б. А. Серебренникова. За время учебы в аспирантуре Л. Е. Кириллова прошла хорошую научную школу, овладев методикой лингвистических исследований и освоив лучшие традиции отечественного и зарубежного финно-угроведения. По объективным причинам тему диссертационной работы ей пришлось поменять, и она стала исследовать микротопонимию бассейна реки Валы.

После окончания аспирантуры молодой ученый возвращается в Удмуртский научноисследовательский институт, заняв должность сначала младшего научного сотрудника, а затем научного сотрудника сектора языка. И уже около 40 лет она трудится в стенах этого научного учреждения.

В октябре 1993 г. Л. Е. Кириллова успешно защитила кандидатскую диссертацию на тему «Микротопонимия бассейна Валы (в типологическом освещении)», впервые в удмуртском языкознании в монографическом плане описав микротопонимию бассейна реки Валы. В работе представлены основные закономерности формирования удмуртской топонимической системы и теоретические основы для ее изучения.

Почти 20 лет (1994-2014 гг.) Л. Е. Кириллова заведовала сначала отделом языкознания, затем отделом филологических исследований Удмуртского института истории, языка и литературы УрО РАН (сейчас Институт является структурным подразделением Удмуртского Федерального исследовательского центра УрО РАН).

Одно из ведущих направлений в научной деятельности юбиляра - удмуртская ономастика. Без преувеличения можно сказать, что своими топонимическими исследованиями она создала новое направление в удмуртском языкознании. На основе анализа большого корпуса архивных и полевых лингвистических материалов, собранных в различных районах Удмуртии и за ее пределами, ею опубликовано свыше 140 научных работ. В их числе особо отметим две авторские монографии, одну коллективную монографию, методические и учебные пособия для вузов и школ, разделы в обобщающих трудах, статьи в энциклопедических изданиях, центральных и зарубежных журналах. 
В монографии «Микротопонимия бассейна Валы (в типологическом освещении)» ${ }^{1}$, изданной в 1992 г., впервые с помощью традиционных методов подробно рассматриваются лексикосемантические и структурные типы микротопонимов 80 населенных пунктов Вавожского, Можгинского и Увинского районов Удмуртии в сопоставлении с географическими названиями других регионов Удмуртии и России в целом. Особое внимание в работе уделено роли апеллятивной лексики в образовании удмуртских топонимов и микротопонимов. Все аппелятивы, входящие в состав микротопонимов бассейна Валы, автором подвергнуты этимологическому анализу и по характеру описываемой реалии разделены на 8 семантических групп. С точки зрения лексико-семантических признаков в системе микротопонимии Валы названия, образованные от нарицательной лексики, составляют 47,05 \% от общей доли микротопонимов, названия, образованные от собственных имен, $-51,36 \%$, а названия, этимология которых выяснена недостаточно, $-1,57 \%$. В структурном отношении наиболее распространенными являются сложные наименования (85,41 \%). Доля простых микротопонимов составляет 7,66 \%, эллиптированных - 6,92 \%. Исследователем выявлен ряд особенностей удмуртской микротопонимии, сводимых, по ее определению, к следующему: «а) самый распространенный тип образования - сочетание определяющего слова с определяемым, в роли которого выступает, как правило, аппелятив, обозначающий вид географического объекта; б) наличие сочетаний существительного с послелогом; 3) наличие глагольных конструкций»².

Продолжением разрабатываемой Л. Е. Кирилловой темы «Топонимия Удмуртии», начало которой было положено в предыдущей книге, стала монография «Микротопонимия бассейна Кильмези» ${ }^{3}$, опубликованная в 2002 г. Она написана на основе богатого фактического материала, который был собран автором в 134 населенных пунктах Селтинского, Сюмсинского, Игринского, Красногорского и Якшур-Бодьинского районов, расположенных в бассейне Кильмези. В данной работе названия географических объектов представлены в виде словаря, включающего в себя 5425 наименований, каждое из которых подвергнуто этимологическому анализу. Достаточно подробно автором представлена лексико-семантическая характеристика и структурнословообразовательный анализ микротопонимов. Фронтальное изучение микротопонимии любого региона дает гораздо обширный материал для решения вопроса об употреблении аппелятивов в географических названиях, способствует выявлению новых географических терминов, не встречающихся в других регионах. В частности, в микротопонимах бассейна Кильмези Л. Е. Кирилловой выявлены специфические аппелятивы типа бӧмыр 'небольшой подлесок округлой формы посреди поля', вал'эс 'расчищенный из-под леса под пашню или покос участок земли', йыраӟ ‘изголовье; верхняя часть, начало (чего-л.)', залка 'переулок', л'ипэто 'крытый зерноток', пӧз'ис' nӧз'ыс' 'ключ, родник' и др. Как подчеркивает исследователь, «микротопонимы бассейна Кильмези почти не отличаются от типов географических названий, относящихся к другим регионам Удмуртии, что объясняется одинаковыми географическими условиями и природной средой, спецификой материальной и духовной культуры, языка, которому они принадлежат, и отражают особенности удмуртской микротопонимии в целом. Существенные изменения, происходящие в названиях рассматриваемого нами региона, являются характерными для всей удмуртской топонимической системы» ${ }^{4}$.

Монографии юбиляра получили высокую оценку не только ученых-лингвистов, но и преподавателей вузов. Они широко используются в качестве учебных пособий студентами Удмуртского госуниверситета.

Л. Е. Кириллова входит в число соавторов коллективной монографии «Историко-культурный ландшафт Камско-Вятского региона» ${ }^{5}$, изданной в 2009 г. и представляющей собой ком-

\footnotetext{
${ }^{1}$ Кириллова Л. Е. Микротопонимия бассейна Валы (в типологическом освещении). Ижевск, 1992 б. 320 с.

2 Там же. С. 198.

${ }^{3}$ Кириллова Л. Е. Микротопонимия бассейна Кильмези. Ижевск, 2002. 571 с.

${ }^{4}$ Там же. С. 421.

${ }^{5}$ Шутова Н. И., Капитонов В. И., Кириллова Л. Е., Останина Т. И. Историко-культурный ландшафт Камско-
} Вятского региона. Ижевск, 2009. 244 с. 
плексное исследование отдельных микрорайонов Камско-Вятского региона с целью выявления особенностей культурного ландшафта в разные исторические эпохи. Широкое привлечение топонимических материалов совместно с археологическими, фольклорно-этнографическими, географическими, экологическими, биологическими и другими данными позволило ярко представить историко-культурный ландшафт таких территорий, как окрестности д. Кузебаево Алнашского р-на Удмуртии, д. Старая Уча, сел Старая Юмья и Нырья Кукморского р-на Татарстана.

В соавторстве с известным топонимистом М. А. Самаровой в 2016 г. юбиляр подготовила и издала учебное пособие «Удмуртская онимия I. Онимы реальной действительности» ${ }^{6}$. Книга состоит из двух частей. В первой рассматриваются общие вопросы теории ономастики, определяется статус ономастики как раздела языкознания, ее объект и предмет изучения, также освещаются вопросы связи ономастики с другими науками. Кроме того, внимание уделяется истории изучения удмуртской ономастики, приводятся сведения об исследователях удмуртской ономастики. Вторая часть учебного пособия посвящена ономастическому пространству, где освещаются вопросы антропонимики, топонимики, а также анализируются космонимы, фитонимы и зоонимы удмуртского языка. Важно отметить, что до настоящего времени последние три типа онимов не были предметом специального изучения в удмуртской ономастике. В учебном пособии представлены приложение с основными ономастическими терминами, a также программа-вопросник, нацеленная на сбор ономастического материала. Таким образом, данное издание представляет собой оригинальную концепцию системно-образной организации ономастического пространства удмуртского языка, выявляющую его специфику и количественную динамику в языковой картине мира.

Большая работа проведена Л. Е. Кирилловой при подготовке географической карты Удмуртской Республики ${ }^{7}$, где впервые, наряду с русскими названиями, обозначены и удмуртские названия населенных пунктов, рек и некоторых других объектов. Список удмуртских названий составлен Людмилой Евгеньевной. Карта была издана в 2009 г. при финансовой поддержке Общества М. А. Кастрена (Финляндия).

Значительное место в научном творчестве Л. Е. Кирилловой занимают работы, связанные с изданием памятников письменности удмуртского языка. В частности, в рамках серии «Памятники культуры Удмуртии» ею подготовлены и опубликованы рукописные памятники удмуртской письменности XVIII в.: «Русско-удмуртский словарь» 3. Кротова ${ }^{8}$ и «Грамматика М. Могилина $\rangle^{9}$ (Мышкина) ${ }^{10}$, более 200 лет лежавших в рукописном виде в архивах библиотек Санкт-Петербурга. Обе книги предваряют вступительные статьи Л. Е. Кирилловой, знакомящие читателя с особенностями подготовки этих изданий. Немалый вклад внесла Людмила Евгеньевна и в издание лингвистического наследия выдающегося просветителя, первого удмуртского ученого, педагога Г. Е. Верещагина. Совместно с коллегой Л. Л. Карповой она подготовила к публикации первую книгу четвертого тома Собрания сочинений Г. Е. Верещагина ${ }^{11}$,

${ }^{6}$ Самарова М. А., Кириллова Л. Е. Удмуртская онимия І. Онимы реальной действительности: учебное пособие. Ижевск: Изд. центр «Удм. университет», 2016. 196 с.

7 Удмуртская Республика: карта = Удмурт Элькунлэн мутусэз: Административной мутус / Удм. ин-т ИЯЛ УрО РАН; ФГУП «Уралаэрогеодезия». Екатеринбург, 2009.

${ }_{8}^{8}$ Кротов 3. Удмуртско-русский словарь: около 5000 слов [= Краткой Вотской словарь съ россїйскимъ переводомъ собранный и по Алфавиту расположенный села Еловскаго Троицкой церкви священникомъ Захарїею Кротовымъ, 1785 г.]. Ижевск, 1995. 286 с. (Памятники культуры Удмуртии).

${ }^{9}$ Могилин М. Краткой отяцкія Грамматики опыть = Опыт краткой удмуртской грамматики. Ижевск, 1998. 203 с. (Памятники культуры Удмуртии: Лингвистическое наследие).

${ }^{10}$ По более поздним исследованиям автором рукописи «Краткой отяцкія Грамматики опытъ» является М. А. Мышкин (подробнее об этом см.: Чураков B. C. Об авторе рукописи «Краткой отяцкой грамматики опыт» // Пермистика 15 : Диалекты и история пермских языков во взаимодействии с другими языками. Ижевск, 2015. С. 342-345).

${ }^{11}$ Верещагин Г. Е. Собрание сочинений. Т. 6. Кн. 1 (Труды по языкознанию). Ижевск, 2002. 291 с. (Памятники культуры). 
в которую вошли опубликованная и рукописная грамматики удмуртского языка («Руководство к изучению вотского языка» (Ижевск, 1924) и «Удмурт грамматика: кык кылын - удмурт кылын, дзюч кылын») и изданная работа «О книгахъ на вотскомъ языкъ» (Вятка, 1895).

Л. Е. Кириллова является ответственным редактором ряда крупных коллективных работ, монографических исследований, материалов международных и региональных форумов, сборников научных статей. В частности, под ее руководством и при непосредственном участии подготовлен к изданию академический «Удмуртско-русский словарь» ${ }^{12}$. Словарь включает также удмуртско-русский и русско-удмуртский указатели географических названий - названия населенных пунктов и рек, составителем которого является юбиляр. Кроме того, Л. Е. Кириллова является одним из авторов фундаментального лексикографического труда «Русско-удмуртский словарь» ${ }^{13}$, увидевшего свет в 2019 г. Эти академические словари являются нормативными двуязычными лексикографическими трудами и служат справочными изданиями для широких кругов населения республики. В 2012 г. совместно с В. П. Осотовой ею опубликован «Русскоудмуртский и удмуртско-русский медицинский словарь» ${ }^{14}$, являющийся первым опытом составления подобного типа отраслевого словаря. Издание включает в себя также краткий разговорник и перечень медицинских терминов с толкованием на русском языке.

Признания заслуживает активная деятельность юбиляра в сохранении и развитии удмуртского языка. В течение ряда лет она является членом Республиканской термино-орфографической комиссии при Министерстве по делам национальностей Удмуртской Республики, основной задачей которой является развитие удмуртского литературного языка, упорядочение терминотворчества, орфографии и топонимии. Она проявила себя и как переводчик с русского на удмуртский язык нормативных документов органов государственной власти Удмуртской Республики.

Людмила Евгеньевна активно сотрудничает с зарубежными финно-угорскими научными центрами. В частности, она участвует в международном проекте «Onomastica Uralica», в рамках которого подготовила и опубликовала серию работ по удмуртской ономастике. Также при непосредственном ее участии между Удмуртским институтом истории, языка и литературы УдмФИЦ УрО РАН и Институтом языкознания Венгерской академии наук разрабатывалась исследовательская тема «Финно-угорское и удмуртское языкознание». В течение многих лет совместно с научным сотрудником Института языкознания Венгерской академии наук Жужанной Шаланки она выезжала в лингвистические экспедиции в различные районы Удмуртской Республики, в результате чего был собран большой, во многом оригинальный материал.

Высокий рейтинг популярности трудов Л. Е. Кирилловой достигается и благодаря вовлечению богатого материала полевых практик, в которых она продолжает принимать самое непосредственное участие. Экспедиционная деятельность Людмилы Евгеньевны началась с первых же дней ее работы в Институте. География ее топонимических и фольклорно-диалектологических поездок не ограничивается Удмуртской Республикой. Фронтально обследованы ею микротопонимы населенных пунктов, расположенных в бассейнах Валы, Кильмези и Ижа; совершались поездки и в другие удмуртские регионы, в частности в Глазовский, Дебесский и Кизнерский районы Удмуртии, а также в Агрызский и Менделеевский р-ны Татарстана и в Кильмезский р-н Кировской области. Ею проведено более 70 экспедиций, в результате которых собраны уникальные образцы лингвистического, этнографического и фольклорного материала. Особую ценность представляют выявленная микротопонимия исчезнувших деревень, а также антропонимия, космонимия, позволяющая воссоздать прошлое и настоящее деревень, языковую картину мира удмуртов, отражающая географическую среду, на которой развивается культура удмуртского народа во всех ее разновидностях: материальной, социальной и духовной.

\footnotetext{
12 Удмуртско-русский словарь: ок. 50000 слов / Отв. ред. Л. Е. Кириллова. Ижевск, 2008. 925 с.

${ }^{13}$ Русско-удмуртский словарь: В 2 т. Более 55000 слов. Т. 1 (А-О) / Отв. ред. Л. М. Ившин. Ижевск, 2019. 936 с.; Русско-удмуртский словарь: В 2 т. Более 55000 слов. Т. 2 (П-Я) / Отв. ред. Л. М. Ившин. Ижевск, 2019. 1016 с.

${ }^{14}$ Русско-удмуртский и удмуртско-русский медицинский словарь / Сост. В. П. Осотова, Л. Е. Кириллова. Ижевск, 2012. $246 \mathrm{c}$.
} 
Ученый поддерживает тесные связи с вузами и школами республики. На протяжении ряда лет она вела занятия на географическом факультете, также на факультете удмуртской филологии (ныне Институт удмуртской филологии, финно-угроведения и журналистики) Удмуртского государственного университета; руководила курсовыми и дипломными работами студентов. Юбиляром подготовлены материалы для школьного учебного пособия по краеведению «Удмуртское краеведение» (Ижевск, 1992; 1999), «Отчий край» (Ижевск, 1993; 2000). Кроме того, Людмила Евгеньевна неоднократно выступала с лекциями перед учителями в Институте повышения квалификации и переподготовки работников образования Удмуртской Республики, перед учителями и школьниками в Республиканском центре учащейся молодежи, на семинарах библиотекарей. Многократно оппонировала кандидатские диссертации, готовила отзывы ведущей организации на кандидатские и докторские диссертации.

Л. Е. Кириллова - участник ряда всесоюзных, всероссийских, зональных, республиканских и других конференций, а также международных конгрессов и симпозиумов по финноугроведению в России и за рубежом. В ее содержательных докладах и выступлениях на международных научных конгрессах в Сыктывкаре (1985), Ювяскюля (1995), Тарту (2000), Йошкар-Ола (2005), Пилишчаба (2010) рассматриваются актуальные вопросы удмуртской и пермской ономастики.

Много делает юбиляр для лингвистического воспитания носителей языка. В ее научных и публицистических трудах, в выступлениях по радио и телевидению подчеркивается мысль о необходимости бережного отношения к родному языку и его традициям, к сохранению родной речи, национально-культурных ценностей, поскольку судьба любого народа органично сплетена с судьбой его языка.

Наряду с научной деятельностью, Л. Е. Кириллова ведет большую общественную работу. С 1994 г. она является координатором Общества М. А. Кастрена (Финляндия) по Удмуртской Республике; активно участвовала в работе Всеудмуртской ассоциации «Удмурт кенеш» и в Обществе удмуртских женщин «Удмурт нылкышно кенеш». В 2003-2007 гг. работала ученым секретарем специализированного совета по защите кандидатских диссертаций по специальности 10.01.09 - фольклористика.

Людмила Евгеньевна пользуется большим авторитетом среди коллег. Она честный и бескомпромиссный в науке человек, талантливый ученый, энергичный и неутомимый труженик. Исследовательский дар и преданность отличают ее, наделенную талантом и выносливостью, в выполнении любого дела, к которому она относится ответственно и со всей отдачей.

Дорогая Людмила Евгеньевна! Мы, коллеги и друзья, от всей души поздравляем Вас с замечательным юбилеем! Желаем крепкого здоровья, неиссякаемой жизненной энергии и оптимизма, новых творческих достижений, плодотворной научной деятельности, душевной молодости и успехов в реализации новых идей и проектов!

Поступила в редакцию 27.10.2020

Карпова Людмила Леонидовна, доктор филологических наук, старший научный сотрудник Удмуртский институт истории, языка и литературы УдмФИЦ УрО РАН 426034, Россия, г. Ижевск, ул. Ломоносова, 4 ФГБОУ ВО «Удмуртский государственный университет» 426034, Россия, Ижевск, Университетская, 1 E-mail: karpovalud@rambler.ru 


\section{L. Karpova}

\section{SECRETS OF TOPONYMIC SOUND (TO THE ANNIVERSARY OF L. E. KIRILLOVA)}

DOI: $10.35634 / 2224-9443-2020-14-4-754-760$

The article is devoted to the anniversary of Ljudmila Jevgenjevna Kirillova, an Udmurt linguist, Honored scientist, Candidate of Philology. The author focuses on her scientific and creative activity and analyzes her contribution to the development of Udmurt linguistics, in particular considering her publications in onomastics. Her works are in demand not only among the academic community and teachers of higher education, but also of all those who are interested in traditional culture. During her activities she conducted a large number of toponymic and folklore-dialectological expeditions, the geography of which, in addition to the Udmurt Republic, covers the Republic of Tatarstan, the Kirov region. The name of the Udmurt linguist is known not only on a Russian scale, but also outside of it. L. E. Kirillova is a returning participant in international conferences, congresses.

Keywords: Finno-Ugrian studies, the Udmurt language, onomastics, toponymy, anniversary, L. E. Kirillova.

Citation: Yearbook of Finno-Ugric Studies, 2020, vol., issue, pp. 754-760. In Russian.

Received 27.10.2020

Karpova Ludmila Leonidovna,

Doctor of Philology, Senior Research Associate Udmurt Federal Research Center of the Ural Branch of the Russian Academy of Sciences

T. Baramzinoy st., 34, Izhevsk, Russian Federation, 426067

Udmurt State University

Universitetskaya st., 1/2, Izhevsk, Russian Federation, 426034

E-mail: karpovalud@rambler.ru 